\title{
ASPEK KULTURAL \\ "BISMILLAHIRRAHMÂNIRRAHIM" DALAM KEISLAMAN ORANG BUTON: KAJIAN TERHADAP KABANTI AJONGA INDA MALUSA
}

\author{
Ali Rosdin \\ Universitas Haluoleo Kendari \\ Jalan M.T Haryono, Anduonou, Kendari, Sulawesi Tenggara 93132 \\ email: rosdinali@gmail.com
}

Abstract

This study aimed at describing to what extent expression bismillahirrahmânirrahim influenced Islamic lives of Buton people in the past. The object of the study is script kabanti Ajonga Inda Malusa as H. Abdul Ganiu's work. The study focuses on understanding the meanings constructed in kabanti Ajonga Inda Malusa by looking at its relationship with cultural elements and historical background of Buton people. In understanding the phrase bismilllahirrahmânirrahim, it used hermeneutic method supported with the sociological theory of literature, that views literature as (1) a reflection of its supporting society, (2) a document that records cultural social reality and the bias of the reality of society in its time, and (3) other aspects related to a society in accordance with conventions and historical background in its cultural social framework. The results showed that the statement bismilllahirrahmânirrahim is a tradition of Sufi poets in the past Buton Sultanate to start their work, which can be interpreted as a form of practice of Islamic refinement that always refers to the al Quran and Hadis. In the Islamic context of Buton people, the phrase bismillahirrahmânirrahim then explored and elaborated into whole aspects of life, the world and the hereafter.

Penelitian ini bertujuan untuk mendeskripsikan sejauhmana ungkapan bismilllahirrahmânirrahim berpengaruh dalam kehidupan keislaman orang Buton pada masa lampau. Objek kajiannya adalah naskah kabanti Ajonga Inda Malusa karya H. Abdul Ganiu. Kajian difokuskan pada pemahaman 
terhadap makna yang dibangun dalam kabanti Ajonga Inda Malusa dengan melihat hubungannya dengan unsur budaya dan latar belakang kesejarahan masyarakat Buton. Dalam memahami ungkapan bismilllahirrahmânirrahim, digunakan metode hermeneutik yang ditopang dengan teori sosiologi sastra, yang memperhatikan karya sastra sebagai (1) cermin masyarakat pendukungnya, (2) dokumen yang mencatat kenyataan sosial budaya serta bias dari realitas masyarakat pada masanya, dan (3) aspek-aspek lain yang berhubungan dengan masyarakat sesuai dengan konvensi dan latar belakang kesejarahan dalam kerangka sosial budayanya. Hasil penelitian menunjukkan bahwa pernyataan bismilllahirrahmânirrahim merupakan tradisi para penyair sufi di Kesultanan Buton masa lampau dalam mengawali setiap karyanya, yang dapat dimaknai sebagai wujud pengamalan adab Islam, yang senantiasa merujuk pada al Quran dan al Hadits. Dalam konteks keislaman orang Buton, pernyataan bismilllahirrahmânirrahim kemudian digali dan dijabarkan dalam seluruh aspek kehidupannya, dunia dan akhirat.

Keywords: culture, Buton moeslim, kabanti Ajonga Inda Malusa

\section{Pendahuluan}

Kebudayaan masyarakat atau kelompok masyarakat suatu bangsa dapat tercermin dari gagasan, nilai, dan norma peraturannya, yang merupakan suatu rangkaian konsep abstrak mengenai apa yang dianggap penting dalam kehidupannya, seperti pola kehidupan, aktivitas, pikiran dan perasaan, dan sikap hidupnya (Koentjaraningrat, 1974: 15). Sejumlah aspek kebudayaan itu dapat tercermin dalam sebuah karya sastra. Dengan mempelajari suatu karya sastra, tidak saja dapat mempelajari hubungan sejarah dengan peradaban bangsa pemilik sastra itu, namun dapat dikatakan memasuki hidup baru dalam masyarakat pemilik sastra tersebut. Orang akan mengetahui keadaan budaya suatu masyarakat, perkembangan kejiwaan, perasaan, pikiran, dan gagasan masyarakat melalui ungkapan pengarangnya (Baroroh et al, 1994: 91).

Salah satu jenis karya sastra di Buton adalah kabanti, yang berarti syair, puisi, atau nyanyian (Anceaux, 1987: 51). Pada masyarakat Buton, kabanti telah berkembang jauh sebelum masyarakat Buton menganut ajaran Islam, yang berkembang dalam bentuk tradisi lisan. Ketika agama Islam masuk ke Buton pada abad XVII yang memperkenalkan tradisi tulis-menulis, maka pada saat itulah tradisi kabanti yang berupa tulisan (naskah) mulai berkembang pula (Niampe, 1999: 1). Karya sastra kabanti bagi masyarakat Buton merupakan sarana untuk mengekspresikan dinamika kehidupan. Berbagai masalah kehidupan, baik masalah keagamaan maupun masalah kemasyarakatan, disampaikan 
melalui sastra kabanti ini. Dengan demikian, sastra kabanti bagi masyarakat Buton dapat berfungsi sebagai (1) sarana untuk menyampaikan petuah-petuah tentang tuntunan dan falsafah hidup yang dilandasi oleh ajaran agama Islam, (2) sarana pendidikan, pengetahuan, dan filsafat, dan (3) sarana berekspresi dan bersastra (berkesenian).

Pada tulisan (naskah) kabanti, terdapat ciri keislaman pada permulaan teksnya sebelum memasuki untaian bait, yaitu perkataan "Bismillahirrahmânirrahim". Hal ini menunjukkan ketaatan penulis teks kabanti terhadap ajaran agama Islam, yang menganjurkan dalam melakukan sesuatu pekerjaan harus diawali dengan menyebut nama Allah, agar apa yang dikerjakan mendapat berkah dari-Nya. Sebagai teks untuk tujuan syiar Islam, teks kabanti juga umumnya diakhiri dengan bershalawat kepada Nabi Muhammad SAW dengan perkataan "wassalam" atau kalimat "washallallahu 'ala sayidinâ muchammad wa 'ala 'âlihi washahbihi ajma'in."

Tulisan ini bertujuan mendeskripsikan sejauhmana ungkapan bismilllahirrahmânirrahim berpengaruh dalam kebudayaan masyarakat Buton pada masa lampau. Adapun sumber kajiannya adalah teks naskah kabanti Ajonga Inda Malusa karya H. Abdul Ganiu, yang hidup pada masa pemerintahan Sultan La Ode Muhammad Idrus Kaimuddin (1824-1851), Sultan Buton XXIX. Dalam bahasa Wolio (Buton), Ajonga Inda Malusa artinya 'pakaian yang tidak luntur'. Naskah ini terdapat dalam berbagai koleksi pribadi di Baubau, di antaranya ditemukan pada koleksi Abdul Mulku Zahari dengan nomor kode 302/Wolio/20 yang disalinnya pada tahun 1974, dan beberapa salinan lainnya terdapat pada Arsip Nasional RI dan Perpustakaan Nasional RI di Jakarta serta di KITLV Leiden Belanda, masing-masing dalam bentuk mikrofilm. Naskah ini berisi tentang akhlak serta sejarah dan kebudayan Buton.

\section{Tergantung pada Bismillahirrahmânirrahim}

Sebagai karya sastra yang lahir dari kondisi sosial budaya masyarakat Kesultanan Buton, kabanti Ajonga Inda Malusa berkaitan erat dengan keberadaan sosial budaya masyarakat Islam Buton pada masa karya itu diciptakan. Oleh karena itu, untuk memahami kandungan isi kabanti ini tidak dapat dilepaskan kaitannya dengan konteks budaya dan kesufian penyairnya. Dengan demikian, terdapat hubungan antara kabanti ini dengan keislaman masyarakat Kesultanan Buton dan kesufian penyairnya, sebagai sumber penciptaan dan terciptanya syair tersebut dengan memahaminya, sebagai cermin masyarakat dan fungsi sosialnya (Swingewood, 1972:31, Damono, 1979:3). Ditegaskan, bahwa setiap 
teks merupakan mosaik kutipan-kutipan. Teks ini terdapat dua jenis, yaitu teks secara khusus (tertulis) dan teks secara umum (world atau semesta), yaitu semesta sosial budaya masyarakat tertentu, maka teks kabanti Ajonga Inda Malusa ini adalah teks khusus yang merupakan transformasi semesta sosial budaya masyarakat Buton pada masa lampau (Kristeva, 1980:139) .

Untuk menelusuri dan memahami makna kabanti Ajonga Inda Malusa ini secara menyeluruh, dapatlah digambarkan dalam diagram berikut.

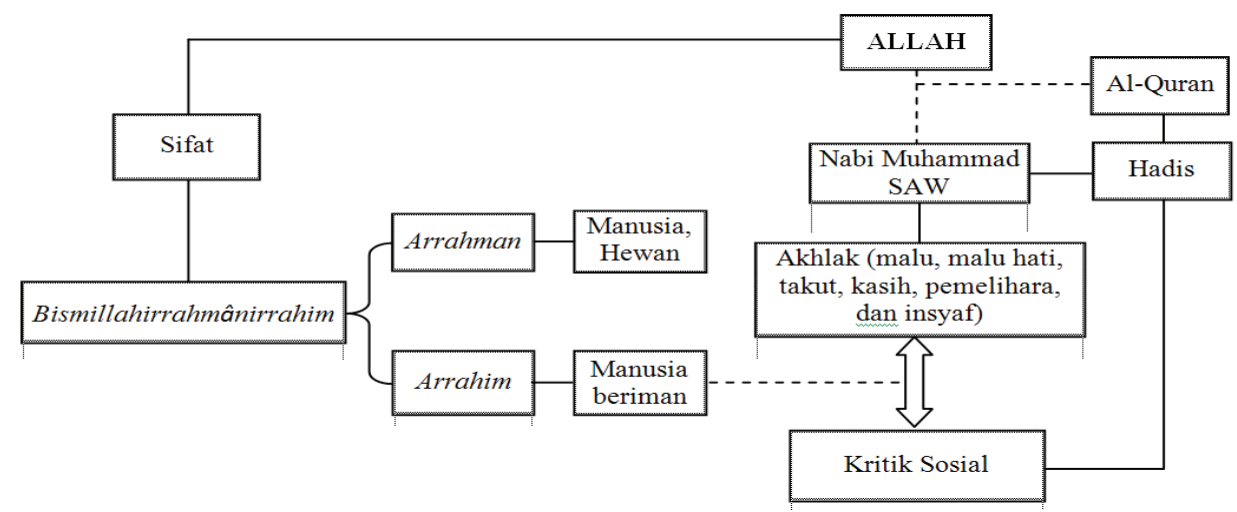

Gambar 1. Diagram makna kabanti Ajonga Inda Malusa

Pada diagram di atas jelas terlihat bahwa isi keseluruhan kabanti Ajonga Inda Malusa ini adalah kupasan makna kalimat basmalah "Bismillahirrahmânirrahim" dalam konteks suasana kehidupan Kesultanan Buton pada masa karya itu diciptakan. Kabanti Ajonga Inda Malusa yang merupakan pencitraan sejumlah akhlak Rasulullah Muhammad SAW boleh diibaratkan hanyalah sebuah peta yang harus sungguh-sungguh dipelajari dan dikuasai dalam pelayaran di samudera basmalah (Bismillahirrahmânirrahim) yang tidak seorang pun mampu mengetahui batas keluasan dan kedalaman maknanya.

\section{Basmalah}

Kabanti ajonga Inda Malusa dibuka dengan kalimat basmalah "Bismillahirrahmânirrahim". Hal ini merupakan tradisi yang dilakukan oleh para penyair sufi di Kesultanan Buton dahulu. Tradisi yang demikian ini tidak hanya dimaknai sebagai suatu gaya kepenyairan atau sebagai suatu wujud pengamalan adab Islam yang dianjurkan dalam memulai atau menjalankan suatu pekerjaan yang baik, tetapi juga mencerminkan kredo kabanti para penyair sufi di Kesultanan Buton. Menulis kabanti (syair) bagi para ulama 
sufi bukanlah sekadar penyaluran minat-bakat semata, tetapi merupakan suatu usaha kreatif dalam menghidupkan dan memajukan dakwah Islam kepada khalayak masyarakat Islam pada umumnya. Bagi ulama sufi di Buton, menulis kabanti adalah ibadah kepada Allah SWT. Segala yang disampaikan melalui syairnya (kabanti) tidak boleh sedikit pun ada yang bertentangan dengan isi al Quran dan Sunah Rasulullah Muhammad SAW.

Di kalangan masyarakat Buton, tugas kesufian seperti itu lazim disebut sebagai usaha "meluruskan apa yang sesungguhnya sudah lurus, menjelaskan apa yang sesungguhnya sudah jelas”. Maksud dari kalimat tersebut adalah sesuatu yang sesungguhnya sudah lurus dan sudah jelas itu tidak lain adalah al Quran dan hadits.

Kabanti Ajonga Inda Malusa dimulai dengan bait yang menegaskan kemahaluasan samudera hikmah yang dikandung oleh kalimat basmalah. Di samping itu, ditegaskan pula perbedaan cakupan makna antara ar Rahman dan ar Rahim yang terangkai langsung dengan nama zat Tuhan (Bismillah) pada kalimat basmalah tersebut. Dengan penegasan demikian, penyair menggiring pemaknaan ar Rahman dan ar Rahim kepada keinsyafan tentang lemah dan hinanya diri (hamba) di hadapan Allah yang telah menciptakannya dan alangkah agung dan mulianya Allah Yang Maha pengasih dan Maha penyayang kepada hamba-Nya.

Perbedaan sifat dan cakupan makna ar Rahman dan ar Rahim dijadikan cermin penerang melihat perbedaan dan pertentangan antara diri (hamba) dan Tuhan, antara rohani dan jasmani, antara manusia dan binatang, antara dunia dan akhirat, dan antara surga dan neraka. Dengan pengetahuan bahwa sifat Tuhan ar Rahman cakupannya lebih luas tapi masanya terbatas hanya di dunia ini, sedangkan ar Rahim cakupannya lebih sempit tapi masanya tidak terbatas (sejak di dunia sampai akhirat), penyair meyakinkan setiap diri (hamba) untuk lebih memilih dan mencintai yang kekal daripada yang fana. Keyakinan dalam menentukan pilihan itu dijabarkan dalam bentuk pertentangan antara diri (hamba) yang fana dan Tuhan yang kekal, pertentangan antara kehidupan dunia (alam fana) dan kehidupan akhirat (alam baqa), dan pertentangan antara jasad (yang fana) dan roh (yang kekal).

Sebagian ulama berpendapat bahwa ar Rahman dan ar Rahim adalah dua nama Allah yang mengandung satu pengertian yang sama, tetapi sebagian yang lain membedakan pengertian keduanya (Jailani, 2011: 67). Dengan demikian, penafsiran ar Rahman yang terdapat dalam kabanti ini menunjukkan penyairnya 
(K.H. Abdul Ganiu) termasuk kelompok ulama yang membedakan pengertian antara ar Rahman dan ar Rahim. Di samping itu, dijelaskan pula oleh Jailani, bahwa ar Rahman sasarannya adalah jasmani, sedangkan ar Rahim sasarannya adalah rohani (hati atau jiwa). Perbandingan seperti ini sesuai pula dengan pengungkapan dalam kabanti Ajonga Inda Malusa ini mengenai wujud ar Rahman sebagai rezeki atau harta benda, seperti dalam firman Allah, "Sesungguhnya Allah adalah Dialah maha pemberi rezeki yang mempunyai kekuatan lagi sangat kokoh" (QS. al Dzariyat 51: 58).

Dengan pemahaman dan keinsyafan seperti yang dikemukakan di atas, penyair hendak membawa diri (hamba) kepada suatu sikap hidup untuk menjadi hamba yang terpilih mendapatkan nikmat yang mengalir dari sifat Allah Yang Maha penyayang (ar Rahim). Untuk itu, diri (hamba) harus memilih sikap hidup untuk lebih mengutamakan kehidupan akhirat yang kekal daripada kehidupan dunia yang fana, untuk lebih mengutamakan kesucian dan kemuliaan rohnya yang kekal daripada jasad/jasmaninya yang fana.

Hamba pilihan yang berhak mendapatkan nikmat Allah dan sosok hamba yang suci dan mulia di mata Allah SWT yang diketengahkan dalam kabanti ini disimbolkan sebagai ajonga inda malusa, yang kemudian dijadikan judul syair ini. Dalam bahasa Wolio, ajonga inda malusa terdiri atas kata "ajonga" yang bermakna 'pakaian' dan frase "inda malusa" yang berarti "tidak luntur”. Namun kata "ajonga” kemudian mengalami perkembangan makna, yakni selain bermakna denotatif 'pakaian', juga telah bermakna konotatif 'sifat' atau 'kelakuan'. Dari analogi makna konotatif inilah kemudian kata "ajonga" pun berkembang maknanya yang berarti pula 'sifat/prilaku'.

Kata "ajonga” yang bermakna 'sifat' atau 'prilaku' itu diperkuat pula oleh bagian keterangan "inda malusa” yang berarti 'tidak luntur'. Dari sudut pandang penyair sufi, dunia serta seluruh isinya bersifat fana, tidak ada yang abadi. Kalau demikian, ajonga (pakaian) pasti juga akan lusuh dan musnah. Pakaian yang tidak pernah lusuh dan musnah adalah sifat dan akhlak mulia setiap muslim yang diperbuat selama hidupnya di dunia ini, seperti sifat dan akhlak mulia yang dicontohkan oleh Nabi Muhammad SAW.

Dari perspektif pemaknaan tersebut, secara struktural ajonga inda malusa dipandang sebagai 'keseluruhan' yang merupakan 'pensifatan isi cerita' (Ikram, 1980: 21). Dengan demikian, pembaca diarahkan untuk memusatkan perhatian pada 'sifat' atau 'prilaku' yang tidak pernah usang sebagai pusat keseluruhan teks. Tampaknya 'sifat' atau 'prilaku' ini sebagai 
unsur struktur mengandung fungsi yang potensial sehingga kita dapat mempersiapkan diri dalam membangun pemahaman dan menyatukan presepsi tentang 'pakaian yang tidak pernah luntur', yang sesungguhnya kesemuanya itu dilingkupi oleh Bismillahirrahmânirrahim.

Selanjutnya, dalam untaian kabanti ini dinyatakan secara tajam dan menarik pertentangan antara pakaian jasmani (tubuh kasar) yang pasti luntur dan hanya berguna di dunia fana ini, sedangkan pakaian rohani atau akhlak yang baik tidak akan pudar dipakai dan berguna sejak di dunia yang fana ini sampai di akhirat yang kekal kelak.

Tês sarona opu Allâhu

Kupebângi kulaguyaka kabanti

Oni Wolio kabanti inciya siy

Bismillahi saro Allâhu siytu

Osiytumo sarona dzatina opu

ar Rahmâni osarona shifatuna

Oma'anana atopene kalambuna

Apepatai incana duniâ siy
Dengan nama Tuhan Allah

Kumulai kumelagukan puisi/syair

Bahasa Wolio puisi ini

Bismillah nama Allah itu

Itulah nama zat Tuhan ar Rahman nama sifat-Nya

Maknanya amatlah tingginya

Menyeluruh di dalam dunia ini

(KAIM:1)

Kabanti Ajonga Inda Malusa diawali dengan pernyataan opu Allâhu (Tuhan Allah) dan kemudian disusul dengan pernyataan /oni Wolio kabanti inciya siy/ (berbahasa Wolio syair ini). Kombinasi opu Allâhu (Tuhan Allah) merupakan ungkapan yang terdiri atas dua kata yang mengacu pada pengertian yang sama, sehingga dapat digunakan salah satunya untuk merujuk kepada 'Yang Disembah'. Dalam bahasa Indonesia, dikenal ungkapan antara lain seperti Tuhan yang maha pengasih atau Allah Yang Maha pengasih, Tuhan Yang Maha penyayang atau Allah Yang Maha penyayang. Namun, dalam bahasa Wolio kombinasi opu Allâhu (Tuhan Allah) memiliki aspek kultural dalam kehidupan masyarakat Buton. Kata opu tidak hanya merujuk pada Allah tetapi juga lazim digunakan untuk sebutan Sultan atau ulama-ulama suci yang dikeramatkan. Penegasan bahwa /syair ini berbahasa Wolio/ dapat pula dimaknai sebagai tonggak peringatan bahwa pemaknaan syair ini haruslah dalam konteks kehidupan dan kebudayaan masyarakat Wolio (Buton). Demikian pula halnya dengan pemaknaan opu atau waоpu yang disebut penyair dalam kabanti ini.

Kata opu atau waорu dalam bahasa Wolio dapat diartikan sebagai 'Tuhan' atau 'yang disembah dan dimintai pertolongan'. Kata opu/waopu 
dalam praktik kehidupan orang Buton (pemakai bahasa Wolio) sehari-hari selain digunakan untuk sebutan Tuhan juga digunakan untuk sebutan sultan atau pemimpin spiritual yang diagungkan oleh masyarakat pendukungnya. Meskipun menggunakan sebutan yang sama (opu/waopu), pemaknaannya tetaplah berbeda antara penyebutan opu/waopu untuk Sultan dengan penyebutan ори/waopu bagi Allah. Hubungan antara keduanya ini antara lain seperti yang dilukiskan dalam ungkapan tradisional masyarakat Buton (berbahasa Wolio) yang berbunyi "poromu inda posângu pogâ inda kôlota" (berkumpul tidak menyatu, terpisah tidak berjarak).

Demikianlah jiwa keislaman yang hidup dalam suasana Kesultanan Buton pada masa lampau itu dan masih diwarisi oleh sebagian generasi Islam Buton pada masa kini, bahwa hubungan hamba dan Tuhan itu begitu dekat, senantiasa berkumpul dan bahkan sangat berhimpitan dan tidak berjarak lagi, tetapi keduanya tetap terpisah dan tidak mungkin menyatu. Kata opu memang sama-sama digunakan baik untuk menyapa diri Sultan maupun untuk menyebut zat Tuhan Allah SWT. Penyebutan diri Sultan dengan opu dapat bermakna sebagai Khalifatullah fil ardh (Q.S. al Baqarah 2:30), yaitu pemegang amanat, mandataris, dan kuasa, untuk merealisasikan dan menjabarkan kehendak kekuasaan Allah di muka bumi. Khalifah bukan berarti manusia memiliki kedudukan yang sama dengan Allah, tetapi manusia sebagai pengemban amanah dan sebagai makhluk yang diberi potensi akal dan dengan perintah-perintah tertentu diharapkan mampu untuk mengkaji dan menyingkap rahasia alam dan memanfaatkannya bagi kemaslahatan umat manusia. Meskipun demikian, dalam jiwa keislaman masyarakat Buton tetap terukir jelas bahwa opu (yang disembah) yang ditujukan pada Sultan berbeda dengan ори (Tuhan) yang ditujukan pada zat Allah (Hamka, 2001:207-209). Sebutan opu yang ditujukan pada diri Sultan bermakna konotatif, sedangkan sebutan opu (Tuhan) yang ditujukan pada zat Allah bermakna denotatif atau sebenarnya (Malim, 1961: 11).

Sebutan opu yang ditujukan pada diri Sultan merupakan pengagungan perintah Tuhan dan penyembahan terhadap hukum-hukum Allah yang dipersonifikasikan oleh sang Sultan Khalifah Tuhan di bumi ini. Pemahaman demikian ini antara lain terlihat pada cara Sultan disembah oleh rakyat jelata sebagaimana yang dituturkan oleh Malim berikut ini.

“... Si Rakyat jelata duduk sambil memegang tanah dan menatap Sultan, lalu tunduk menyembah. Duduk merendahkan diri perlambang kepatuhan kepada yang dihadapi, yaitu Khalifah Tuhan, perintah Tuhan yang dipersonifikasikan 
di diri Sang Sultan, sambil tidak melupakan bahwa diri yang mendukung perintah Tuhan yang dihadapinya itu adalah manusia jua, hamba Allah yang sama dengan dia. Di situlah ia menyentuh tanah sambil menatap Sultan, (yang bermakna-pen) mengingatkan pada Sang Sultan: 'Hai Sultan, ingatlah bahwa jasadmu itu dari tanah dan akan kembali ke tanah, sadarlah bahwa kita sama, bahwa yang kusembah hanyalah perintah Tuhan yang engkau dukung itu.'... Dan Si Sultan, demi menerima pandangan itu, insyaflah dia akan dirinya, akan keadaannya sebagai ciptaan dari Yang Maha Pencipta. Ingatlah ia bahwa ia pun menyembah yang disembah oleh yang menyembahnya itu, bahwa mereka sama-sama menyembah Yang Satu itu, demi Yang Satu itu. Kemudian Sang Sultan agak mengelak atau memejamkan mata, atau agak memandang ke atas seraya mengucapkan 'La-ilaha-illallah' (Malim, 1961:12).

Dari kutipan di atas jelaslah bahwa meskipun Sultan disebut juga opu dalam bahasa Wolio, rakyat dan sultan di Kesultanan Buton tetap sama-sama menyadari dan selalu saling mengingatkan bahwa di hadapan opu Allâhu (Tuhan Allah) mereka (rakyat dan Sultan) sama sebagai hamba Allah. Sebutan opu terhadap diri Sultan hanya bermakna simbolis, yakni perintah Tuhan atau hukum Allah yang terpikul di pundak Sultan, yang dipersonifikasikan oleh diri Sultan yang disembah secara lahir, tetapi secara batin penyembahan itu hanya tertuju pada Tuhan Yang Satu, yaitu Allah SWT.

Sebutan opu dalam bahasa Wolio dapat ditujukan kepada Tuhan dan dapat pula ditujukan kepada manusia (makhluk-Nya). Sebutan opu Allâhu adalah terjemahan Bismillah yang merupakan penegasan Tuhan Yang Mahaesa yang menamai diri-Nya Allah, "Sesungguhnya Aku adalah Allah, tiada Tuhan selain Aku, maka sembahah Aku" (QS. Thaha 20:14).

Berikutnya ditegaskan pula bahwa Bismillah itulah nama Tuhan Allah atau nama zat Allah. Penegasan Bismillah setelah opu Allâhu (Tuhan Allah) seperti di atas bukanlah suatu kebetulan atau sekadar informasi biasa, melainkan di balik itu semua terkandung suatu ajaran ketauhidan yang mendasar bagi umat Islam, khususnya masyarakat Islam di Kesultanan Buton yang belum sepenuhnya bebas dari pengaruh animisme dan Hinduisme. Rangkaian konsep ketuhanan pada kutipan di atas adalah (1) opu/waopu (Tuhan) adalah nama Tuhan yang bersifat umum dan jamak; (2) opu Allâhu (Tuhan Allah) adalah nama Tuhan umat yang beragama Islam; (3) Bismillah/Allah (dengan nama Allah/Allah) adalah nama Tuhan dalam Kitab Suci al Quran. Dengan perkataan lain, opu/waopu dan opu Allâhu adalah nama Tuhan dalam bahasa 
kebudayaan Buton, sedangkan Bismillah/Allah adalah nama Tuhan dalam bahasa kitab suci al Quran.

Penegasan Bismillah sebagai nama zat Tuhan dalam kitab suci al Quran itu juga mengandung pengertian yang menyarankan bahwa penyebutan nama Tuhan dengan Bismillah itulah yang mengandung hikmat dan berkah. Bismillah itu pula nama Tuhan yang tunggal, Yang Mahaesa, karena kata Allah (Bismillah) tidak boleh disandang oleh siapa pun selain Allah SWT. Jadi berbeda dengan penyebutan nama Tuhan dengan opu yang dapat disandang pula oleh seorang Sultan di Kesultanan Buton dahulu.

Selain itu, dalam tradisi masyarakat Buton sapaan "Wa" biasanya digunakan untuk menyebut seorang perempuan. Ketika menyebut Tuhan dengan sapaan Waopu, maka yang dimaksudkannya adalah kualitas feminimitas atau jamal dalam diri Tuhan. Para sufi kerap membuat klasifikasi dari 99 nama-nama Tuhan yang disebut Asmaul Husna. Dari semua nama tersebut, dapat dipilah dalam dua katagori yaitu kualitas maskulinitas atau kelelakian (jalal), misalnya Maha Perkasa, dan katagori lainnya adalah kualitas feminimitas atau keperempuanan (jamal), misalnya Maha pengasih dan Maha penyayang. Melalui penyebutan tersebut, penyair merindukan Tuhannya sebagai sosok yang jamal, sosok yang pengasih dan penyayang.
Âmiyna waopu tarimaiya
Amin ya Allah terimalah
Satotûna tarimamu amakasu

(KAIM:270)

Bila Anda berkata, "Allah", maka apa yang Anda ucapkan itu telah mencakupi semua nama-Nya yang lain; sedangkan jika Anda mengucapkan nama-Nya yang lain - misalnya ar Rahim, al Malik, dan seterusnya, maka ia hanya menggambarkan sifat rahmat atau sifat kepemilikan-Nya. Di samping itu, dijelaskannya pula bahwa tidak satu pun dapat dinamai Allah selain Allah SWT, baik secara hakikat maupun secara majas. Adapun nama-nama sifatNya yang lain secara umum dapat disandang oleh makhuk-Nya (Rachman, 2008: 78).

Dalam kabanti ini, penyebutan nama Tuhan dengan Bismillah itu dijelaskan pula sebagai penyandang sifat ar Rahman dan ar Rahim yang selain maknanya sangat luas juga memiliki begitu banyak keutamaan bila diamalkan dalam kehidupan seorang muslim sehari-hari. Rasulullah bersabda, "Sesungguhnya umatku akan datang di hari Kiamat sambil membaca Bismillahirrahmânirrahim, 
sehingga timbangan amal kebajikan mereka menjadi berat. Oleh karenanya, umat-umat yang lain bertanya kepada nabi mereka masing-masing, "Apakah yang membuat timbangan amal kebajikan umat Muhammad menjadi berat?" Dijawab, "Sebab, mereka memulai pembicaraan mereka dengan tiga nama dari nama-nama Allah yang mulia, yaitu Allah, ar Rahman, dan ar Rahim (Jailani, 2011: 98-100).

(1) Bismillahirrahmânirrahim adalah perbendaharaan bagi orang-orang yang selalu berzikir, keagungan bagi orang-orang kuat, pelindung bagi orang-orang lemah, cahaya bagi orang yang mencintai Allah, dan kebahagiaan bagi orang-orang yang merindukan bertemu dengan-Nya.

(2) Bismillahirrahmânirrahim adalah ketenangan bagi roh, keselamatan bagi jiwa, cahaya bagi hati, berkah bagi segala urusan, mahkota bagi mereka yang yakin terhadap Allah, lampu penerang bagi mereka yang sedang menempuh jalan menuju Tuhan, dan bekal bagi mereka yang sedang larut dalam kecintaan kepada-Nya.

(3) Bismillahirrahmânirrahim adalah nama zat Allah Yang maha memuliakan dan menghinakan hamba-hamba-Nya.

(4) Bismillahirrahmânirrahim adalah pembuka semua surah al Quran.

(5) Bismillahirrahmânirrahim adalah kalimat yang dengan mengungkapkannya mulut menjadi baik, nikmat menjadi sempurna, bencana menjadi tertolak, dan umat Islam menjadi istimewa.

(6) Bismillahirrahmânirrahim adalah kalimat yang memadukan antara keagungan (keperkasaan) yang dikandung oleh ungkapan Bismillah, dan keindahan yang dikandung oleh ungkapan ar Rahman ar Rahim. Barangsiapa memiliki keagungan-Nya, pasti memiliki kekuatan. Barangsiapa yang mengakui keindahan-Nya, pasti memperoleh kehidupan.

(7) Bismillahirrahmânirrahim adalah kalimat yang mengombinasikan antara kekuasaan (qudrat) dan kasih sayang (rahmah); Qudrat memperhitungkan segala ketaatan, sedangkan rahmah menghapus segala dosa.

Di balik keutamaan basmalah seperti di atas inilah antara lain penyair menguraikan pengertian basmalah dalam kerangka pengenalan diri yang sejati dalam hubungan yang tidak terpisahkan dengan pengenalan Tuhan (Allah) yang kekal. Dengan pengenalan diri dalam hubungan dengan Tuhan secara 
lebih baik dan benar, dapatlah diharapkan seseorang dapat menghadapi dan menjalani kehidupannya di dunia ini secara lebih baik dan benar pula.

Bagi umat Islam, akhlak Rasulullah Muhammad SAW adalah contoh teladan yang paling sempurna baik dalam soal pengenalan diri maupun soal menjalani hidup secara baik dan benar itu. Akhlak Rasulullah yang semulia itulah yang disimbolkan sebagai "ajonga inda malusa" atau dalam bahasa Indonesianya sebagai "pakaian yang tidak pernah lusuh".

Bila memperhatikan keutamaan kalimat basmalah antara lain seperti di atas, maka penegasan makna dan pengertian Bismillah sebagai nama zat Allah dan ar Rahman sebagai nama sifat-Nya juga dapat bermakna pentauhidan diri bagi seorang penyair sufi seperti penyusun kabanti ini. Adapun ungkapan ar Rahim yang melekat pada kalimat basmalah tersebut diuraikan lebih jauh dalam kaitan yang tidak terpisahkan dengan ar Rahman, seperti yang populer sebagai sifat rahmah (kasih sayang Allah) kepada hambanya.

Bari-baria makhaluqu atipua

Hengga kawana bari-baria binata

Momasegana indâ kande anana

Tê moduka kawanamo kâfiri

Osaturuna adawua radzaqiy

Osiytumo tao imendeuakana

Osâliki mopêluna opuna

Beya peolo dalana âkherati

(KAIM: 1)
Semua makhluk adalah rata Hingga sampai pada semua binatang Yang jagoan tidak makan anaknya

Dan juga sampai pada kafir

Musuhnya diberikan rezeki

Itulah yang membuatnya tidak mau

Salik yang menyukai Tuhannya

Selalu mencari jalannya akhirat

\section{Ar Rahman}

Sifat ar Rahman, Allah Yang Maha Pengasih itu meliputi makhluk di seluruh dunia dan merata tidak ada perbedaan baik antara makhluk manusia dan binatang maupun antara manusia yang bersifat baik (beriman dan takwa) dan manusia yang bersifat buruk (kafir). Wujud sifat Allah Yang Maha Pengasih itu bernama rezeki yang dibagikan secara merata kepada semua makhluk ciptaannya di muka bumi ini. Bahkan orang yang memusuhi-Nya atau melawan ajaran-Nya pun tetap diberikan rezeki-Nya.

Tuhan Maha pengasih ditegaskan sebagai sifat pemberi rezeki atau harta yang merata pada semua makhluk yang hendak mengusahakannya, tanpa membedakan jenis atau derajat makhluk yang bersangkutan. Baik hewan maupun manusia, baik orang beriman maupun orang kafir semua berpeluang 
mendapatkan rezeki atau harta benda dunia ini. Jika bukan karena "kasih Tuhan” walau hanya seberat sayap nyamuk, maka pastilah orang-orang kafir itu tidak akan mendapatkan rezeki walau hanya setetes air sekali pun.

Dalam sifat Maha pengasih itu belum ada klasifikasi halal dan haram, terserah pada makhluk atau manusia yang berangkutan. Itulah sebabnya penyair mengingatkan agar manusia (beragama) jangan melampaui batas hajat dalam mengejar harta dunia ini. Jika sampai melampaui batas hajat dalam memburu harta dunia ini, maka hal itu akan menjadi racun yang membinasakan serta menjadi tembok penghalang antara hamba dengan Tuhannya.

Bagi orang-orang saleh yang mencintai Tuhannya, tidak akan mau terpedaya dengan rezeki atau harta dunia yang dilimpahkan kepada semua mahkluk Tuhan secara merata seperti itu. Mereka lebih memilih mencari jalannya akhirat. Mereka tidak mau mengejar harta dan tahta di dunia ini, mereka takut menerima pemberian orang lain, karena mereka sadar bahwa sangatlah kafir orang memusuhi hukum Allah, yang hanya menyediakan bekalnya dengan harta dunia yang disukainya.

Beya peolo ârasi aratâ
Ameriyaka beya pokana kadawu
Okâfiri mia saturuna opu
Sabutunamo soa sandata bakuna

Tê aratâ duniâ ipêluna

Kâpâka atopeneaka mpî

Pûna alaloaka châjati isara'i

Amembalimo racu manga pekamatena

(KAIM: 1-2)
Untuk mencari tahta harta

Takut pada semua pemberian

Sangat kafir orang seteru Tuhan

Bila hanya menyediakan bekalnya

Dengan harta dunia yang disukainya Sebab karena jika hal itu keterlaluan Ringkasnya melewati hajatnya di sarai

Akan menjadi racun yang membinasakan

Kemudian diingatkan pula oleh penyair bahwa mengambil rezeki atau harta dunia itu cukuplah sebatas hajat. Bila berlebihan mengejar harta dunia, maka harta itu akan berubah menjadi racun yang membinasakan kita serta menjadi dinding pemisah yang tebal antara hamba dengan Tuhannya. Penyair mencontohkan kafir yang bisa menikmati harta dunia baik dengan jalan halal maupun haram, itu disebabkan mereka hanya semata-mata memburu kesenangan dunianya, sedangkan untuk kehidupan akhiratnya sudah tidak ada sama sekali nikmat dari Tuhannya, mereka menjalani siksa neraka selama-lamanya. 
Tea membali rindi makapa iopu

Kâpâka oaratâ charamu tê chalala

Kabarangkala tapeolo aratâ

Tapasabutu châjati isara'i

(KAIM: 2)
Dan menjadi dinding tebal pada Tuhan

Sebab karena harta haram dan halal

Karena itu jika mencari harta

Sesuaikan menurut hajatnya sarai

Kita juga jangan tertipu dengan kafir yang sukses menikmati harta dunia. Kafir itu sudah memilih hanya hidup untuk kehidupan dunianya, sehingga seluruh nikmat rezekinya sudah berakhir hanya di dunia ini dan tidak ada lagi yang tersisa untuk kehidupan akhiratnya.

Pemahaman sifat Allah ar Rahman dalam kabanti ini meliputi (a) salah satu nama sifat Tuhan yang berarti Maha pengasih; (b) salah satu sifat Tuhan yang pengertiannya mencakupi seluruh kehidupan makhluk Tuhan di muka bumi ini; (c) Allah Maha Pemberi rezeki kepada semua makhluknya tanpa membedakan antara manusia dan binatang atau antara yang mukmin dan yang musyrik; (d) Allah Maha Pemberi rezeki hanya terbatas dalam kehidupan umatnya di dunia ini; dan (e) sifat Allah Maha pengasih yang dapat mengangkat atau sebaliknya menjatuhkan harkat dan martabat seseorang.

\section{Ar Rahim}

Selanjutnya, kesadaran tertinggi penyair tentang sifat ar Rahim, Allah Maha penyayang kemudian digambarkan pula sebagai berikut.

Indâ kosaro siytu oni'imati

Sabutunamo akosaro radzaqiy

Kâpâka satanga o'ulamâ

Akôniyaka oni'imati siytu

Kapupuyana incana akapujia

Asadâdâ namisina kalapena

Taoyakamo shifatuna rachiymu

Ôpu yitu atantu ibatuana

(KAIM: 3)
Tidak dinamakan itu nikmat

Hanya saja bernama rezeki

Sebab karena sebagian ulama

Mengatakan nikmat itu

Penghabisannya di dalam kepujian

Tetap terasa kebaikannya

Sebab itu sifat rahim

Tuhan itu pasti pada hamba-Nya

Sesungguhnya tidaklah semua "rezeki" yang kita dapatkan di dunia ini dapat dikatagorikan sebagai "nikmat" dari Allah Yang Maha Pengasih. Kalau rezeki merupakan perwujudan sifat Allah Yang Maha Pengasih, maka "nikmat" merupakan perwujudan sifat Allah Yang Maha Penyayang. Kalau 
"rezeki" berhak diperoleh semua makhluk dan hanya terbatas di dunia ini, maka "nikmat" hanya berhak didapatkan oleh manusia yang memiliki sifat-sifat terpuji di mata Allah SWT dan tidak hanya dirasakan di dunia ini tetapi juga hingga di akhirat kelak. Jailani (2011) menjelaskan bahwa ar Rahim bersifat khusus karena hanya berlaku bagi hamba-hamba-Nya yang beriman, yakni berupa pemberian taufiq dan hidayah kepada mereka (hamba-hamba-Nya yang beriman).

Manusia terpuji dan dijamin mendapatkan "nikmat" kasih-sayang Allah SWT itu hanyalah mereka yang termasuk ke dalam golongan mukmin, yakni orang-orang beriman menurut dasar-dasar keimanan yang disampaikan atau dibawakan oleh Rasulullah Muhammad SAW. Golongan mukmin atau orang-orang beriman itulah yang digambarkan dalam firman Tuhan sebagai golongan orang-orang yang pandai mensyukuri nikmat dari Tuhannya. Bagi mereka yang pandai mensyukuri nikmat dari Tuhannya di dunia ini, niscaya Tuhan akan menambahkan nikmat itu dalam kehidupannya yang kekal di akhirat kelak.

Mukmim yang dijamin akan mendapatkan curahan sifat Allah Yang Maha Penyayang itu adalah mukmin yang dapat meneladani akhlak nabinya, Nabi Muhammad SAW. Akhlak atau sifat-sifat mulia Nabi Muhammad SAW itu amatlah banyak dan terbatas kemampuan umatnya untuk merincinya satu per satu. Dengan rendah hati penyair menyatakan bahwa hanya ada enam sifat Rasulullah Muhammad SAW yang ia ketahui, yaitu (1) malu, (2) malu hati, (3) takut, (4) kasih, (5) pelihara, dan (6) insyaf. Keenam sifat inilah yang menjadi pakaian mukmin atau orang-orang beriman, yang dimaksud sebagai pakaian yang tidak pernah luntur atau usang, yang dijamin akan membawa nikmat dari kehidupan dunia yang fana sampai ke kehidupan akhirat yang abadi.

Gambaran nikmat yang demikian itu antara lain seperti diungkapkan penyair berikut ini.

Sô syukuru oge-oge iopuna

Incema-incema mu'umini mosyukuru

Oni'imati incana duniâ siy

Arangania naile iakherati

Tê ni'imati sorogâ mokakala

Bâbâna naile ipenamina

Omu'umini isorogâ fu'ali
Bersyukur sebesar-besarnya pada Tuhan Siapa-siapa mukmin yang bersyukur Atas nikmat di dalam dunia ini

Ditambahkannya esok di akhirat

Dengan nikmat surga yang kekal Mula-mula esok yang akan dirasakan Mukmin di surga fuali 
Osiytumo sorogâ ipewau

Itulah surga yang dibuat-Nya

(KAIM: 4)

Puncak dari segala nikmat dari Tuhan (Allah SWT) itulah surga fuali, yakni ke delapan buah surga yang diberitakan dalam kitab suci al Quran. Semua surga itu memiliki nama sendiri-sendiri, yang masing-masing berisi macam-macam jenis nikmat tersendiri pula. Surga yang terakhir (dari kedelapan surga itu) disebut sebagai "Taman Nikmat yang Mahatinggi".

Kenikmatan hidup di surga yang kekal selama-lamanya hanya diperuntukkan bagi mukmin yang selalu mensyukuri nikmat Tuhannya, yang selalu ridha dan taslim pada segala hukum dan ketentuan dari Tuhannya, yang tidak terbatas kesabarannya dalam menghadapi segala ujian dan kadar buruk dari Tuhannya, yang selalu ingat dan memuja Tuhannya dalam segala aktivitas hidupnya, yang selalu bersalawat kepada nabinya Nabi Muhammad SAW. Mukmin seperti itulah yang akan masuk ke dalam surga Allah SWT, yang akan menemui zat Tuhannya, yang akan mendapatkan safaat dari nabinya Nabi Muhammad SAW, yang akan merasakan nikmat yang tiada tara, nikmat yang tidak pernah terbayangkan dalam seluruh perjalanan hidupnya di dunia ini, nikmat bagi mukmin yang meliputi seluruh lahir dan batinnya.

Sebagai guru dan ulama yang menegakkan siar agama Islam, penyair menyampaikan tujuannya menulis kabanti ini yaitu untuk dijadikan sebagai salah satu bahan bacaan yang berguna dalam membangun kepribadian mukmin seperti yang dilukiskan sebelumnya. Secara lebih khusus ditegaskan bahwa kabanti ini ditulis untuk dibaca oleh murid-muridnya yang menyukainya, yang menyukai kehidupan di surga yang kekal dan yang ingin terhindar dari panasnya api neraka dan segala siksaan di dalam neraka, karena dianggap mengandung tazkir (peringatan), seperti peringatan tentang kematian (kehidupan akhirat), peringatan kelemahan diri atau keterbatasan manusia, bahaya amal, tipu daya setan dan cara mengatasinya, kemurahan Allah melimpahkan rahmat dan nikmat-Nya, kelalaian manusia dalam mensyukuri rahmat dan nikmat Allah, kehinaan dunia (keburukan, kepalsuan, dan kehancuran janjinya), bahaya dan dahsyatnya siksaan di akhirat, dan sebagainya seperti karya yang dipujikan oleh (al Ghazali, 1985: 56).

Siy sângu kabanti asantaonga

Beya rangoa muriku mopêluna
Inilah satu puisi/syair yang pantas

Agar didengar muridku yang menyukainya 
Kamangantalo naile iâkherati

Momasinana sorogâ momalangana

Tê malingu giuna ni'imatina

Atêmiaka kapanena narakâ

(KAIM:8)
Kemenangan esok di akhirat

Yang menyukai surga yang tinggi

Dan segala aneka macam nikmatnya

Untuk menepis panasnya api neraka

Dengan perkataan lain bahwa kabanti ini ditulis untuk menyampaikan suatu ajaran tentang keutamaan mencintai kehidupan akhirat yang kekal dan janganlah sampai kita lalai menghabiskan kesempatan hidup kita di dunia ini hanya untuk memburu harta dunia yang fana ini sehingga kelak kita akan menyesal selama-lamanya. Ajaran itu adalah "kesucian hati" dan "kemuliaan akhlak" sesuai hokum Tuhan yang disampaikan melalui rasul-Nya nabi Muhammad SAW.

Sifat Allah ar Rahim dalam KAIM ini dapatlah dipahami sebagai (a) salah satu nama sifat Allah yang berarti Yang Maha penyayang; (b) salah satu sifat Allah yang dikhususkan kepada hamba-Nya yang beriman dan pandai bersyukur; (c) sifat Allah yang perwujudannya pada diri hamba dinamakan nikmat; (d) sifat Allah Pemberi Nikmat yang diterima oleh hamba-Nya sejak dalam kehidupan dunia yang fana ini sampai pada kehidupan akhirat yang kekal; dan (e) sifat Allah yang khusus bagi mukmin yang memiliki akhlak terpuji seperti akhlak Rasulullah Muhammad SAW.

\section{Simpulan}

Aspek kultural Bismillahirrahmânirram dalam konsep keagamaan orang Buton memperlihatkan dinamika keistimewaan dan indahnya ajaran Islam, yang berperan memberikan dorongan kreatif dan kekuatan dalam rangka siar Islam yang disampaikan melalui kabanti. Landasan Islam dalam kabanti adalah pengalaman-pengalaman keruhanian yang penuh makna dengan menggunakan bahasa simbolik. Kabanti mengekspresikan pengalaman estetik transendental yang berhubungan erat dengan tauhid, penyaksian bahwa Tuhan itu satu, atau dengan perkataan lain Tuhan sajalah sebenarnya Yang Ada dan yang selain-Nya secara hakiki tiada. Rujukan penghayatan penyair adalah al Quran dan al Hadis. Karena kabanti merupakan ekspresi dari pengalaman kesufian, maka tidak mengherankan apabila kabanti mengungkapkan renungan dan falsafah hidup yang bertujuan meningkatkan taraf hubungan jiwa manusia dengan Kenyataan Tertinggi seperti yang terdapat dalam kabanti Ajonga Inda Malusa. 
Salah satu konsep keislaman orang Buton yang cukup terkenal di kalangan pewaris Islam Buton hingga sekarang adalah konsep pengenalan hakikat diri yang fana sebagai jalan kepada pengenalan hakikat Tuhannya yang kekal. Konsep pengenalan diri ini telah terukir sebagai mukaddimah kitab Murtabat Tujuh yang resmi sebagai UU Kesultanan Buton pada masa itu. Menurut Malim (1961), pandangan sufi mengenai diri yang tak terpisahkan dengan Tuhan sering menunjuk ayat-ayat di dalam al Quran dan al Hadis, seperti QS Shad 38:72 yang berbunyi, "Aku hembuskan jiwa-Ku ke dalam Adam" dan ucapan (Hadits) antara lain berbunyi, "al insanu sirriy, wa anna sirruhu” yang berarti 'Manusia itu rahasia-Ku dan Aku rahasianya'. Teka-teki diri pada ayat dan Hadits seperti di atas itulah yang digali melalui kalimat Bismillahirrahmanirrahim.

Pencapaian akhlak mulia yang sesuai dengan tuntunan ajaran agama Islam perlu diamalkan dan ditindaklanjuti dengan perbuatan, dan semuanya itu bermula dari "Bismillahirrahmânirrahim". Dalam teks kabanti Ajonga Inda Malusa, penyair secara tersirat juga menawarkan konsep pengenalan Allah, diri, dunia, dan akhirat.

\section{Daftar Pustaka}

Al Ghazali. 1985. Ihya al Ghazali. Terjemahan Tk. H. Ismail Yakub. Jakarta: Faizan.

Al Quran dan Terjemahannya. 1993. Diterjemahkan oleh Yayasan Penyelenggara Penerjemah/Penafsir Al Quran, Departemen Agama RI. Semarang: Asy Syifa.

Anceaux, J.C. 1987. Wolio Dictionary (Wolio-English-Indonesian). Dordrecht - Holland/Providence-USA: Foris Publication Holland.

Baroroh-Baried, Siti, et al. 1985. Pengantar Teori Filologi. Yokyakarta: BPPF Seksi Filologi Fakultas Sastra Universitas Gadjah Mada.

Damono, Sapardi Djoko. 1978. Sosiologi Sastra: Sebuah Pengantar Ringkas. Jakarta: Pusat Pembinaan dan Pengembangan Bahasa.

Ganiu, Haji Abdul. 1974. Ajonga Inda Malusa ("Pakaian yang Tidak Luntur") awal abad ke-19. Penyalin Abdul Mulku Zahari. Koleksi Abdul Mulku Zahari berkode 302/Wolio/20, Baubau.

Hamka. 2001. Tafsir Al-Azhar. Jilid I. Jakarta: Pustaka Panji Mas. 
Ikram, Achadiati. 1980. Hikayat Sri Rama: Suntingan Naskah disertai Telaah Amanat dan Struktur. Jakarta: Universitas Indonesia.

Jailani, Syekh Abdul Qadir. 2011. Wasiat Terbesar sang Guru Besar. Terjemahan Abdul Badruzaman dan Nunung Burhanuddin. Jakarta: Sahara.

Koentjaraningrat. 1974. Kebudayaan, Mentalitas, dan Pembangunan. Jakarta: Gramedia.

Kristeva, Julia. 1980. Desire in Laguage: A Semiotic Approach to Literature and Art. USA: Columbia University Press.

Malim, La Ode. 1961. Membara di Api Tuhan. Jakarta: Proyek Penerbitan Buku Sastra Indonesia dan Daerah Depdikbud.

Niampe, La, et al. 1999. Naskah Buton: Inventarisasi dan Pencatatan (Laporan Penelitian). Kendari: Manassa Cab. Buton - Bappeda Tingkat II Buton.

Rachman, M. Fauzi. 2008. Delapan Kalimat al-Thayyibah, Ringan di Lisan Berat di Timbangan Amal. Bandung: Mizan Pustaka.

Swingewood, Alan and Diana Laurenson. 1972. The Sociology of Literature. London: Granada Publishing Limited.

el Harakah Vol.16 No.1 Tahun 2014 